\title{
Determinan keputusan menabung kaum buruh pada perbankan syariah di Kudus: Peran mediasi niat menabung
}

\author{
Holif Annisa ${ }^{1}$, Saiful Anwar ${ }^{1, *}$ \\ ${ }^{1}$ Fakultas Ekonomi dan Bisnis Islam Negeri Salatiga, Indonesia \\ ${ }^{*}$ Korespondensi (e-mail: saifulanwarmieta@iainsalatiga.ac.id)
}

\begin{abstract}
This study aims to analyze Islamic branding, knowledge, and service quality on the saving decisions of workers, with a saving intention as an intervening variable. This type of research is a quan titative study with a population of Bank Syariah In donesia KCP Kud us customers who make a living as laborers. The sampling technique in this study used purposive sampling, totaling 100 respondents. Workers are chosen to be unique because of their livelihood and ownership of Islamic bank accounts. The analytical tool used is path analysis. The results showed that Islamic branding, service quality, and saving intention positively affected saving decisions. Knowledge is not significant in saving decisions. Saving intention cannot mediate the influence of Islamic branding on saving decisions. Saving intention can mediate the effect of knowledge and service quality on saving decisions. The research contributes to the marketing model and services for workers. However, workers have a different segmentation from other consumers.
\end{abstract}

Keywords: Islamic branding, Knowledge, Service quality, Saving decision, Saving intention

\begin{abstract}
Abstrak
Tujuan penelitian ini adalah untuk menganalisis islamic branding, knowledge dan service quality terhadap saving decision kaum buruh dengan saving intention sebagai variabel intervening. Jenis penelitian ini adalah penelitian kuan titatif dengan populasi nasabah Bank Syariah In donesia KCP Kudus yang bermata pencaharian sebag ai buruh. Teknikpengambilan sampel dalam penelitian ini menggunakan purposive sampling yang berjumlah 100 responden. Buruh dipilih memiliki keun ikan karena mata pencahariannya dan kepemilikan rekening Bank Syariah. Alat analisis yang digunakan adalah path analysis. Hasil penelitian menunjukkan bahwa islamic branding, service quality dan saving intention berpengaruh positif terhadap saving decision. Knowledge tidak signifikan terhadap saving decision. Saving intention tidak dapat memediasi pengaruh islamic branding terhadap saving decision. Saving intention dap at memediasi pengaruh knowledge dan service quality terhadap saving decision. Penelitian berkontirbusi pada model marketing dan pelayanan bagi kaum buruh, bagaimanapun kaum buruh memiliki seg mentasi berbed a dengan konsumen yang lain.

Kata kunci: Branding Islami, Pengetahuan, Kualitas layanan, Keputusan menabung, Niat menabung

How to cite: Annisa', H., \& Anwar, S. (2021). Determinan keputusan menabung kaum buruh pada perbankan syariah di Kudus: Peran mediasi niat menabung. Journal of Management and Digital Business, 1(1), 13-24.
\end{abstract}

\section{Pendahuluan}

Di Indonesia saat ini, perbankan syariah telah memberikan pengaruh pada lingkungan perbankan nasional dan telah mengalami perkembangan yang baik. Perkembangan 
perbankan syariah dari tahun 2016 sampai tahun 2020 telah mengalami perkembangan yang terus meningkat. Baik peningkatan dari aset perbankan syariah maupun jum lah kantor perbankan syariah. Dengan adanya perkembangan perbankan syariah disetiap tahunnya, mengakibatkan persaingan semakin ketat antar kom petitor. Yang mana bank konvensional menjadi pesaingutamanya bank syariah. Bank syariah yang berbasis Al-qur'an dan Hadits diharapkan mampu memenuhi kebutuhan masyarakat untuk menggunakan jasa keuangan syariah (Antonio, 2001).

Saat ini dalam memilih suatu produk atau jasa, nasabah menjadi kritis oleh karena hal itu nasabah dihadapkan dengan suatu decision (keputusan). Decision merupakan suatu tindakan untuk memilih dari dua atau lebih pilihan (Prasetijo \& Ihalauw, 2005). Untuk itu, dibutuhkan informasi yang lengkap, aktual serta terpercaya saat mengambil decision. Persaingan yang semakin ketat mendorong para pemasar untuk lebih inovasi dalam pembuatan strategi bisnisnya. Perbankan syariah dapat melakukan cara dengan menciptakan islamic branding (merek Islam) dalam produk-produknya. Dengan adanya islamic branding akan memberitahukan kepada konsumen bahwa produk tersebut halal sesuai dengan prinsip syariah. Adanya islamic branding akan mendorong konsumen dalam mengambil sebuah decision. Hal ini sejalan dengan penelitian yang menyatakan islamic branding berpengaruh terhadap decision, seperti penelitian yang telah dilakukan oleh Fitriya (2017). Akan tetapi, terdapat perbedaan temuan penelitian menyatakan bahwa tidak ada pengaruh antara Islamic branding terhadap decision. Seperti penelitian yang telah dilakukan oleh Ilamiyah (2020).

Selain menciptakan islamic branding, perbankan syariah juga dapat membuat strategi yang bisa menguatkan dan meningkatkan bank syariah. Yakni dengan menerapkan knowledge (pengetahuan) kepada nasabah mengenai bank syariah dan segala sesuatu yang ada di dalam perbankan syariah lewat kegiatan usahanya. Knowledge merupakan berubahnya perilaku individu karena adanya pengalaman (Kotler, 2000). Karena hal tersebut, seseorang yang mempunyai knowledge yang baik, akan mendorong mereka dalam mengambil sebuah decision. Hal ini sejalan dengan penelitian yang menyatakan knowledge berpengaruh terhadap decision. Sepert penelitian yang telah dilakukan oleh Nurlaeli (2017). Akan tetapi, terdapat perbedaan hasil penelitian yang mana menyatakan bahwa tidak ada pengaruh antara knowledge terhadap decision seperti penelitian yang telah dilakukan oleh Nafiah (2018).

Dalam dunia perbankan, produk/jasa yang dihasilkan cenderung sama. Karena itu, perbankan syariah dapat membuat strategi dengan meningkatkan service quality (kualitas pelayanan) kepada nasabah. Bank syariah dengan memberikan pelayanan yang baik dan memuaskan kepada nasabahnya, akan mendorong mereka dalam mengambil sebuah decision dengan tepat. Hal ini sejalan dengan penelitian yang menyatakan service quality berpengaruh terhadap decision, seperti penelitian yang telah dilakukan oleh Shobirin et al. (2016). Akan tetapi, terdapat perbedaan hasil penelitian yang mana menyatakan bahwa service quality tidak berpengaruh terhadap decision, seperti penelitian yang telah dilakukan oleh Polla et al. (2018). 
Melalui strategi-strategi yang dibuat perbankan syariah tersebut, dapat mempengaruhi nasabah dalam melakukan saving decision. Selain itu, decision yang diambil nasabah juga dipengaruhi oleh intention (minat). Intention adalah suatu keinginan yang terdapat dalam diri seseorang untuk menjalankan suatu kegiatan, terkait dalam hal ini adalah kegiatan dalam pengambilan sebuah decision to save. Hal ini sejalan dengan penelitian yang menyatakan intention berpengaruh terhadap decision, seperti penelitian yang telah dilakukan oleh Anburika (2018). Akan tetapi, terdapat perbedaan hasil penelitian yang mana menyatakan bahwa intention tidak berpengaruh terhadap decision, seperti penelitian yang telah dilakukan oleh Nurlatifah \& Masykur (2017).

Mayoritas nasabah di Bank Syariah Indonesia KCP Kudus ialah berprofesi sebagai buruh. Namun yang menjadi problemaketika dana tabungan tersebuthanya bertahan sebelum satu bulan di rekening nasabah. Hal yang demikian dapat mengurangi potensi dana pihak ketiga yang dapat dijadikan sebagi modal penyaluran pembiayaan untuk meningkatkan profitabilitas Bank Syariah Indonesia. Penelitian ini akan menganalisis lebih lanjut islamic branding, knowledge dan service quality sebagai prediktor nasabah melakukan saving decision. Berdasarkan latar belakang masalah di atas, maka tujuan penelitian ini adalah untuk mengetahui faktor-faktor yang menyebabkan kaum buruh melakukan saving decision dengan saving intention sebagai variabel mediasi pada Perbankan Syariah di Kudus.

\section{Tinjauan Pustaka}

\section{Theory of Planned Behavior (TPB)}

TPB atau Theory of Planned Behavior atau teori perilaku direncanakan adalah perluasan dari TRA atau Theory of Reasoned Action atau teori tindakan beralasan yang diusulkan oleh (Ajzen \& Fishbein, 1980) dan dikem bangkan oleh (Ajzen, 1991). TRA dan TPB adalah sebuahteori yang menjelaskan tentang perilaku manusia. Dimana teori ini dibentuk berdasarkan asumsi dasar bahwa manusia itu berperilaku secara sadar dan mempertimbangkan segala informasi yang ada. Dalam TRA dijelaskan bahwa niat seseorang terhadap perilaku terbentuk karena adanya dua faktor utama yaitu attitude toward the behavior(sikap terhadap perilaku) dan subjective norms (norma subjektif). Sedangkan dalam TPB atau Theory of Planned Behavior ditambahkan satu faktor lagi yakni perceived behavioral control (kontrol perilaku persepsian) (Ajzen, 1991).

\section{Saving Decision (Keputusan Menabung)}

Decision merupakan suatu tindakan untuk memilih dari dua atau lebih pilihan (Prasetjo \& Ihalauw, 2005). Pengambilan decision yang dilakukan nasabah bisa diartikan sebagai suatu proses pemilihan paling baik dari beberapa pilihan yang ada mengenai pilihan bank maupun produk/jasa yang ada pada bank. Karena hal itu, dibutuhkan informasi yang aktual, lengkap serta terpercaya saat mengambil decision.

\section{Islamic branding}

Islamic branding bisa diartikan menggunakan nama yang berhubungan dengan islam atau menam pilkan produk dengan logo halal. Misalnya: rumah sakit muslim, hotel 
syariah, Wardah, dan lainnya (Nasrullah, 2015). Adanya islamic branding akan menginformasikan dan menunjukkan kepada konsumen bahwa produk tersebut merupakan produk halal dan dibuat dari bahan yang baik sesuai dengan ajaran islam.

\section{Knowledge}

Knowledge ialah semua informasi yang dimiliki tentang berbagai produk/jasa, dan pengetahuan lain yang berkaitan dengan produk /jasa tersebut serta informasi yang berkaitan dengan fungsinya sebagai konsumen (Sunyoto, 2013). Knowledge erupakan sebuah pengalaman dan informasi yang dimiliki seorang individu terhadap produk maupun jasa yang dapat merubah perilaku individu tersebut. Knowledge yang meningkat akan memungkinkan seseorang untuk berfikir mengenai produk dalam dimensi yang besar dan dapat membedakan merek-merek yang ada dengan baik.

\section{Service Quality}

Service quality merupakan suatu pemenuhan kebutuhan serta keinginan konsumen dan ketepatan penyampaiannya dalam menyeimbangkan harapan mereka (Tjiptono, 2002). Service quality ialah faktor yang penting bagi perusahaan jasa untuk bersaing pada lingkungan yang kompetitif. Cara mengetahui service quality adalah dengan membandingkan persepsi antara pelayananyang nyata didapatkan konsumen dengan pelayanan yang diharapkan atau diinginkan. Apabila jasa pelayanan yang didapatkan atau dirasakan (perceived service) sesuai dengan apa yang diinginkan, maka service quality dinilai baik dan memuaskan.

\section{Saving Intention}

Intention merupakan suatu hal yang bersifat personal yang berkaitan dengan sikap, seseorang yang tertarik pada suatu objek akan menghasilkan serangkaian perilaku supaya memperoleh impuls dari objek tersebut (Simamora, 2002). Intention adalah aspek psikologis yang dapat mengubah perilaku seseorang agar dapat melakukan aktifitas yang dapat membuat seseorang merasa tertarik pada sesuatu. Intention mampu merubah hal-hal yang belum jelas menjadi lebih jelas (Ibrahim \& Rusdianto, 2016).

Berdasarkan landasan teori di atas, maka gambar model kerangka penelitian sebagaiamana Gambar 1 .

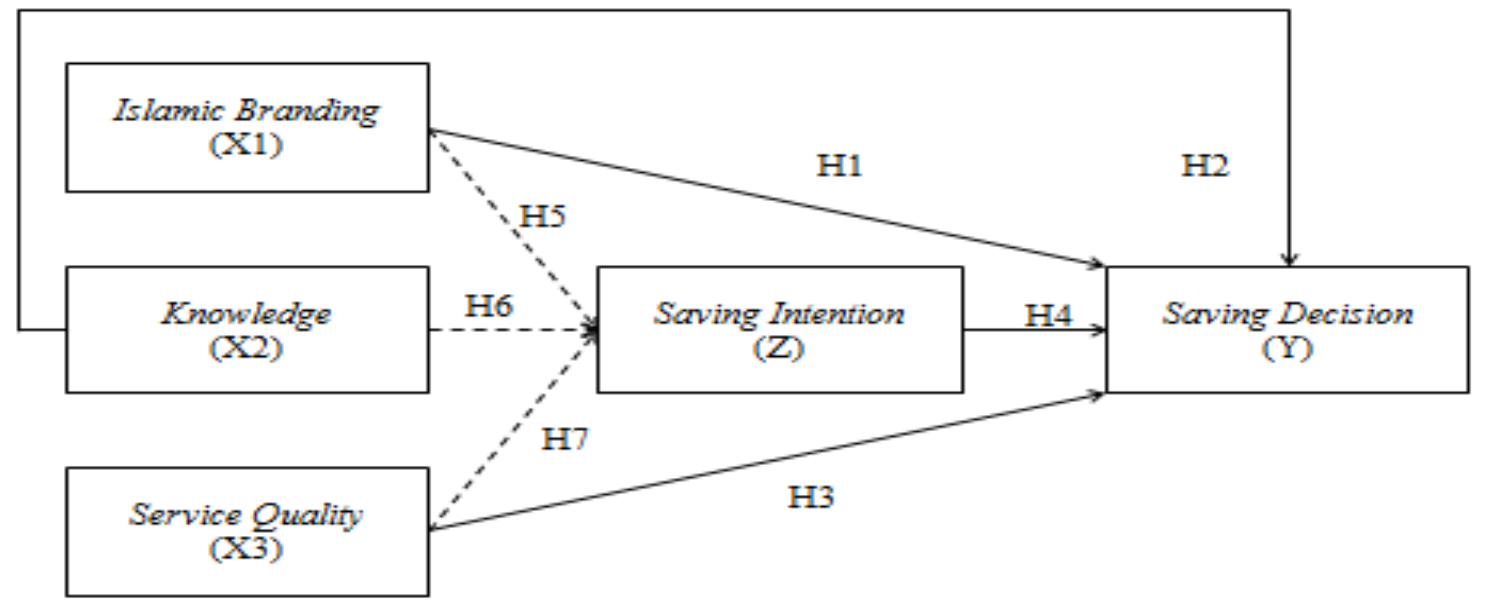

Gambar 1. Kerangka penelitian 
Keterangan: Garis lurus menunjukkan pengaruh langsung variabel bebas terhadap variabel terikat, sedangkan garis putus-putus menunjukkan pengaruh tidak langsung variabel bebas terhadap variabel terikat melalui variabel mediasi.

\section{Metode Penelitian}

Jenis penelitian dalam penelitian ini adalah penelitian kuantitatif. Populasi dalam penelitian ini adalah nasabah Bank Syariah Indonesia KCP Kudus yang berjumlah 20.000 nasabah tabungan. Teknik pengambilan sampel dalam penelitian ini menggunakan purposive sampling yang berjumlah 100 responden. Teknik pengumpulan data menggunakan kuesioner dan diolah menggunakan alat bantu SPSS versi 20. Alat analisis yang digunakan adalah path analysis dengan menggunakan persamaan regresi.

Persamaan 1 yaitu $Z=\beta_{0}+\beta_{1} X_{1}+\beta_{2} X_{2}+\beta_{3} X_{3}+e_{1}$

Persamaan 2 yaitu $Y=\beta_{0}+\beta_{1} X_{1}+\beta_{2} X_{2}+\beta_{3} X_{3}+\beta_{4} Z+e_{2}$

Adapun indikator instrumen dalam penelitian ini adalah sebagai berikut:

Tabel 1 Indikator Instrumen Penelitian

\begin{tabular}{|c|c|c|c|c|}
\hline No. & Variabel & & Dimensi & Pernyataan Kuesioner \\
\hline \multirow[t]{5}{*}{1.} & $\begin{array}{c}\text { Saving } \\
\text { Decision }(\mathrm{Y})\end{array}$ & a. & $\begin{array}{l}\text { Pengenalan } \\
\text { masalah (Problem } \\
\text { Recognation) }\end{array}$ & $\begin{array}{l}\text { Menabung di BSI (Bank Syariah } \\
\text { Indonesia) sesuai dengan kebutuhan } \\
\text { saya }\end{array}$ \\
\hline & $\begin{array}{l}\text { Sumber: Kotler, } \\
2002\end{array}$ & b. & $\begin{array}{l}\text { Pencarian informasi } \\
\text { (Information Search) }\end{array}$ & $\begin{array}{l}\text { Saya berusaha mencari informasi } \\
\text { mengenai produk tabungan di Bank } \\
\text { Syariah Indonesia }\end{array}$ \\
\hline & & c. & $\begin{array}{l}\text { Evaluasi alternatif } \\
\text { (Evaluation of } \\
\text { Alternatives) }\end{array}$ & $\begin{array}{l}\text { Produk tabungan di Bank Syariah } \\
\text { Indonesia memilikibanyak keunggulan }\end{array}$ \\
\hline & & d. & $\begin{array}{l}\text { Keputusan } \\
\text { pembelian } \\
\text { (Purchase Decision) }\end{array}$ & $\begin{array}{l}\text { Saya telah yakin dan memutuskan } \\
\text { untuk menabung di Bank Syariah } \\
\text { Indonesia }\end{array}$ \\
\hline & & e. & $\begin{array}{l}\text { Perilaku pasca } \\
\text { pembelian }\end{array}$ & $\begin{array}{l}\text { Saya merasa puas menabung di Bank } \\
\text { Syariah Indonesia }\end{array}$ \\
\hline \multirow[t]{4}{*}{2.} & $\begin{array}{c}\text { Islamic } \\
\text { Branding }\left(\mathrm{X}_{1}\right)\end{array}$ & a. & Pentingnya merek & $\begin{array}{l}\text { Saya menggunakan produk Bank } \\
\text { Syariah Indonesia karena memiliki } \\
\text { merek yang islami }\end{array}$ \\
\hline & $\begin{array}{l}\text { Sumber: Yunus } \\
\text { et al., } 2014\end{array}$ & b. & Keakraban merek & $\begin{array}{l}\text { Saya menggunakan produk Bank } \\
\text { Syariah Indonesia karena memiliki } \\
\text { merek yang terkenal }\end{array}$ \\
\hline & & c. & $\begin{array}{l}\text { Kepercayaan } \\
\text { konsumen }\end{array}$ & $\begin{array}{l}\text { Merek Islami dapat mempengaruhi } \\
\text { kepercayaan saya terhadap produk } \\
\text { yang akan saya gunakan }\end{array}$ \\
\hline & & d. & Label halal & $\begin{array}{l}\text { Bank Syariah Indonesia menggunakan } \\
\text { label halal dalam setiap produk atau } \\
\text { jasa yang ditawarkan }\end{array}$ \\
\hline 3. & $\begin{array}{l}\text { Knowledge }\left(\mathrm{X}_{2}\right) \\
\text { Sumber: }\end{array}$ & a. & $\begin{array}{l}\text { Pengetahuan } \\
\text { produk }\end{array}$ & $\begin{array}{l}\text { Saya meng etahui produk-produk Bank } \\
\text { Syariah Indon esia yang berpedoman } \\
\text { prinsip syariah }\end{array}$ \\
\hline
\end{tabular}


Engel et al., 1995
b. Pengetahuan pembelian
c. Pengetahuan pemakaian

4. Service Quality $\left(X_{3}\right)$
a. Berwujud atau bukti fisik (tangible)

Sumber: Lupiyoadi, 2009
b. Kehandalan (realibilitas)
c. Ketanggapan (responsives)

d. Jaminan (assurance)

e. Empati (emphaty)

5. Saving Intention a. Minat transaksional (Z)

Sumber: Ferdinand, 2006 b. Minat refrensial

c. Minat preferensial

d. Minat eksploratif
Saya mengetahui lokasi Bank Syariah Ind on esia KCP Kudus

Produk tabungan Bank Syariah Indonesia adalah untuk menyimpan dana

Ruangan pelayanan Bank Syariah Indonesia KCP Kudus bersih dan nyaman

Pegawai Bank Syariah Indonesia dapat diandalkan dalam menangani masalah nasabah

Pegawai Bank Syariah Indonesia cepat dan tepat dalam melayani nasabah

Saya merasa aman saat bertransaksi di Bank Syariah Indonesia KCP Kudus

Pegawai Bank Syariah Indonesia melayani setiap nasabah dengan penuh perhatian

Saya tertarik untuk menabung di Bank Syariah Indonesia karena syarat dan ketentuannya mudah

Saya akan merekomendasikan Bank Syariah Indonesia kepada orang lain

Produk tabungan Bank Syariah Indonesia adalah pilihan utama saya untuk menabung

Saya selalu mencari informasi terbaru mengenai produk yang saya minati

\section{Hasil dan Pembahasan}

\subsection{Hasil penelitian}

Berikut data demografi kaum buruh yang menjadi nasabah tabungan di Bank Syariah Indonesia KCP Kudus.

Tabel 2 Demografi Responden

\begin{tabular}{llcccc}
\hline \multicolumn{1}{c}{ Kategori } & \multicolumn{1}{c}{ kriteria } & Frequency & Percent & Valid \% & Cumulative \% \\
\hline Jenis & Laki-laki & 54 & 54,0 & 54,0 & 54,0 \\
kelamin & Perempuan & 46 & 46,0 & 46,0 & 100,0 \\
& Total & 100 & 100,0 & 100,0 & 100,0 \\
& $<20$ th & 18 & 18,0 & 18,0 & 18,0 \\
\multirow{4}{*}{ Usia } & $20-30$ th & 38 & 38,0 & 38,0 & 56,0 \\
& $31-40$ th & 31 & 31,0 & 31,0 & 87,0 \\
& $>40$ th & 13 & 13,0 & 13,0 & 100,0 \\
& Total & 100 & 100,0 & 100,0 & 100,0 \\
\hline
\end{tabular}




\begin{tabular}{llcccc}
\hline Kategori & \multicolumn{1}{c}{ kriteria } & Frequency & Percent & Valid \% & Cumulative \% \\
\hline \multirow{4}{*}{ Pendidikan } & SD/Sederajat & 2 & 2,0 & 2,0 & 2,0 \\
terakhir & SMP/Sederajat & 12 & 12,0 & 12,0 & 14,0 \\
& SMA/Sederajat & 55 & 55,0 & 55,0 & 69,0 \\
& Diploma/Sarjana & 31 & 31,0 & 31,0 & 100,0 \\
& Total & 100 & 100,0 & 100,0 & 100,0 \\
& $<1$ jt & 8 & 8,0 & 8,0 & 8,0 \\
Pendapatan & $1 \mathrm{jt}-2 \mathrm{jt}$ & 19 & 19,0 & 19,0 & 27,0 \\
& $2,1 \mathrm{jt}-3 \mathrm{jt}$ & 48 & 48,0 & 48,0 & 75,0 \\
& $>3 \mathrm{jt}$ & 25 & 25,0 & 25,0 & 100,0 \\
& Total & 100 & 100,0 & 100,0 & 100,0 \\
\hline
\end{tabular}

\section{Uji Kebajikan Model}

Tabel 3 Model Summary

\begin{tabular}{lrrrr}
\hline Model & $\mathrm{R}$ & $\mathrm{R}$ Square & Adjusted R Square & $\begin{array}{c}\text { Std. Error of the } \\
\text { Estimate }\end{array}$ \\
\hline 1 & $0,767^{\mathrm{a}}$ & 0,588 & 0,571 & 1,510
\end{tabular}

a. Predictors: (Constant), Saving Intention, Service Quality, Islamic Branding, Knowledge Sumber: data yang diolah 2021

Berdasarkan Tabel 3, diketahui koefisien korelasi (R) sebesar 0,767 yang berarti bahwa terdapathubungan sebesar 0,767 antara variabel independen dengan variabel dependen. Koefisien determinasi (RSquare) sebesar 0,588 berarti kontribusi variabel independen dalam mempengaruhi variabel dependen yaitu sebesar 58,8\%, sedangkan sisanya sebesar $41.2 \%$ dipengaruhi variabel lain di luar model.

Tabel 4 ANOVA ${ }^{a}$

\begin{tabular}{lccccc}
\hline \multicolumn{1}{c}{ Model $^{\mathrm{b}}$} & Sum of Squares & df & Mean Square & F & Sig. \\
\hline Regression & 309,622 & 4 & 77,406 & 33,955 & $0,000^{\mathrm{b}}$ \\
Residual & 216,568 & 95 & 2,280 & & \\
\hline a. Dependent Variable: Saving Decision \\
b. Predictors: (Constant), Saving Intention, Service Quality, Islamic Branding, Knowledge \\
Sumber: data yang diolah 2021
\end{tabular}

Berdasarkan Tabel 4, menunjukkan bahwa nilai $\mathrm{F}$ hitung adalah sebesar 33,955 dengan nilai signifikansi 0,000 . Karena probabilitas signifikan 0,000 lebih kecil dari 0,05 , maka variabel independen yaitu islamic branding, knowledge, service quality dan saving intention secara bersama-sama mempengaruhi variabel dependen yaitu saving decision.

\section{Uji validitas pengaruh ( uji t )}

Dari Tabel 5 menunjukkan bahwa nilai signifikansi variabel islamic branding yaitu 0,000 lebih kecil dari 0,05 sehingga menunjukkan islamic branding berpenganuh signifikan terhadap saving decision. Nilai signifikansi knowledge sebesar 0,834 lebih besar dari 0,05 menunjukkan knowledge tidak signifikan terhadap saving decision. 
Nilai signifikansi service quality sebesar 0,038 lebih kecil dari 0,05 sehingga menunjukkan service quality berpengaruh signifikan terhadap saving decision. Dan nilai signifikansi saving intention sebesar 0,015 lebih kecil dari 0,05 sehingga menunjukkan saving intention berpengaruh signifikan terhadap saving decision.

Tabel 5 Coefficients ${ }^{a}$

\begin{tabular}{lcccc}
\hline \multicolumn{1}{c}{ Model } & Coefficients & Std. Error & $\mathrm{t}$ & Sig. \\
\hline (Constant) & $-0,060$ & 2,163 & $-0,028$ & 0,978 \\
Islamic Branding & 0,670 & 0,092 & 7,267 & 0,000 \\
Knowledge & 0,028 & 0,132 & 0,210 & 0,834 \\
Service Quality & 0,227 & 0,108 & 2,100 & 0,038 \\
Saving Intention & 0,304 & 0,123 & 2,465 & 0,015 \\
\hline
\end{tabular}

a. Dependent Variable: Saving Decision

Sumber: data yang diolah 2021

\section{Analisis Jalur (Path Analysis)}

\section{Model 1}

Tabel 6 Model Summary

\begin{tabular}{lrrcc}
\hline Model & $\mathrm{R}$ & $\mathrm{R}$ Square & Adjusted R Square & $\begin{array}{c}\text { Std. Error of } \\
\text { the Estimate }\end{array}$ \\
\hline 1 & $0,502^{\mathrm{a}}$ & 0,252 & 0,228 & 1,252 \\
\hline
\end{tabular}

a. Predictors: (Constant), Service Quality, Islamic Branding, Knowledge

Sumber: data yang diolah 2021

Tabel 7 Coefficients ${ }^{a}$

\begin{tabular}{lrrrr}
\hline Model & Coefficients & Std. Error & $\mathrm{t}$ & Sig. \\
\hline (Constant) & 6,795 & 1,654 & 4,109 & 0,000 \\
Islamic Branding & 0,111 & 0,076 & 1,464 & 0,147 \\
Knowledge & 0,237 & 0,107 & 2,216 & 0,029 \\
Service Quality & 0,200 & 0,087 & 2,291 & 0,024 \\
\hline
\end{tabular}

a. Dependent Variable: Saving Intention

Sumber: data yang diolah 2021

\section{Model 2}

Tabel.8 Model Summary

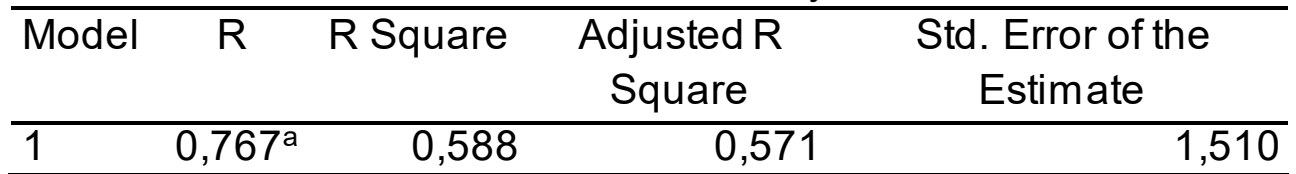

a. Predictors: (Constant), Saving Intention, Service Quality, Islamic Branding, Knowledge Sumber: data yang diolah 2021

Tabel 9 Coefficients $^{\mathrm{a}}$

\begin{tabular}{lrrrr}
\hline Model & Coefficients & Std. Error & $\mathrm{t}$ & Sig. \\
\hline (Constant) & $-0,060$ & 2,163 & $-0,028$ & 0,978 \\
Islamic Branding & 0,670 & 0,092 & 7,267 & 0,000 \\
Knowledge & 0,028 & 0,132 & 0,210 & 0,834 \\
Service Quality & 0,227 & 0,108 & 2,100 & 0,038 \\
Saving Intention & 0,304 & 0,123 & 2,465 & 0,015 \\
\hline
\end{tabular}


a. Dependent Variable: Saving Decision

Sumber: data yang diolah 2021

1. Peran saving intention memediasi antara islamic branding terhadap saving decision

$\mathrm{t}_{1}=\frac{p 4 p 7}{\operatorname{Sp} 4 p 7}=\frac{0,033}{0,023}=1,434$

Nilai thitung $=1,434$ lebih kecil dari t tabel dengan signifikansi $5 \%$ yaitu sebesar 1,984. Maka dapat disimpulkan bahwa saving intention tidak dapat memediasi antara islamic branding terhadap saving decision.

2. Peran saving intention memediasi antara knowledge terhadap saving decision $\mathrm{t}_{2}=\frac{p 5 p 7}{\operatorname{Sp} 5 p 7}=\frac{0,072}{0,033}=2,182$

Nilai $\mathrm{t}$ hitung $=2,182$ lebih besar dari $\mathrm{t}$ tabel dengan signifikansi $5 \%$ yaitu sebesar 1,984. Maka dapat disimpulkan bahwa saving intention dapat memediasi antara knowledge terhadap saving decision.

3. Peran saving intention memediasi antara service quality terhadap saving decision $\mathrm{t}_{3}=\frac{p 6 p 7}{\operatorname{Sp} 6 p 7}=\frac{0,060}{0,027}=2,222$

Nilai $t$ hitung $=2,222$ lebih besar dari $t$ tabel dengan signifikansi $5 \%$ yaitu sebesar 1,984. Maka dapat disimpulkan bahwa saving intention dapat memediasi antara service quality terhadap saving decision.

\subsection{Pembahasan}

Islamic branding berpengaruh positif dan signifikan terhadap saving decision. Semakin kuat islamic branding yang diciptakan, maka saving decision di bank syariah semakin meningkat. Hasil penelitian ini sejalan dengan penelitian yang telah dilakukan oleh Fitriya (2017) yang menemukan bahwa islamic branding berpengaruh positif dan signifikan terhadap decision. Service quality berpengaruh positif dan signifikan terhadap saving decision. Semakin baik service quality yang diberikan, maka saving decision di bank syariah semakin meningkat. Hasil penelitian ini sejalan dengan penelitian yang dilakukan oleh Shobirin etal. (2016) yang menyatakan bahwa service quality berpengaruh positif dan signifikan terhadap decision. Saving intention berpengaruh positif dan signifikan terhadap saving decision. Semakin kuat saving intention seseorang, maka saving decision di bank syariah semakin meningkat. Hasil penelitian ini sejalan dengan penelitian yang dilakukan oleh Anburika (2018) yang menjelaskan bahwa intention berpengaruh positif dan signifikan terhadap decision.

Saving intention dapat mem ediasi pengaruh knowledge terhadap saving decision. Dengan knowledge yang baik akan mendorong seseorang dalam mengambil decision. Yang mana pengambilan decision tersebut didasari adanya intention yang tumbuh dalam diri mereka. Penelitian ini sejalan dengan penelitian yang dilakukan oleh Laila (2018), yang menyatakan bahwa intention dapat memediasi pengaruh knowledge 
terhadap decision. Saving intention dapat memediasi pengaruh service quality terhadap saving decision. Service quality yang baik dan memuaskan dimungkinkan akan menumbuhkan saving intention dalam diri seseorang. Saving intention tersebut yang mendorong mereka untuk mengambil saving decision di bank syariah. Penelitian ini sejalan dengan penelitian yang dilakukan oleh Hidayati (2019) yang menyatakan bahwa intention dapat memediasi pengaruh service quality terhadap decision.

Knowledge tidak berpengaruh terhadap saving decision. Hal ini dimungkinkan karena dari hasil wawancara dengan Branch Operational Supervisor (BOS) Bank Syariah Indonesia KCP Kudus, buruh tersebut menabung di bank syariah karena tempat mereka bekerja telah menjalin kerjasama dengan bank syariah, sehingga buruh tersebut dituntutagar mereka membuka rekening tabungan di bank syariah. Hal tersebut membuat nasabah memiliki knowledge yang belum cukup baik sehingga knowledge tidak berpengaruh secara signifikan terhadap saving decision di bank syariah. Hasil penelitian ini sejalan dengan penelitian yang telah dilakukanoleh Nafiah (2018) yang menyatakan bahwa knowledge berpengaruh positif dan tidak signifikan terhadap decision. Sedangkan penelitian ini tidak sejalan dengan penelitian Nurlaeli (2017) yang menyatakan bahwa knowledge berpengaruh positif dan signifikan terhadap decision.

Saving intention tidak dapat memediasi pengaruh islamic branding terhadap saving decision. Hal itu dimungkinkan karena dengan adanya islamic branding akan membuat nasabah langsung mengambil sebuah saving decision tanpa melalui saving intention. Penciptaan islamic branding membuat nasabah mengetahui bahwa produk tersebut adalah halal sesuai dengan syariat islam, maka tanpa adanya saving intention, mereka telah yakin untuk mengambil sebuah saving decision di bank syariah yang menjalankan aktifitasnya berdasarkan prinsip syariah islam. Penelitian ini sejalan dengan penelitian yang dilakukan oleh Sukron (2019) yang menyatakan bahwa intention tidak dapat memediasi pengaruh islamic branding terhadap decision.

\section{Kesimpulan}

Dari hasil penelitian yang telah dilakukan, maka dapat disimpulkan bahwa islamic branding, service quality dan saving intention berpengaruh positif terhadap saving decision kaum buruh di Bank Syariah Indonesia KCP Kudus. Sedangkan knowledge tidak berpengaruh terhadap saving decision di Bank Syariah Indonesia KCP Kudus dan saving intention tidak dapat memediasi pengaruh islamic branding terhadap saving decision di Bank Syariah Indonesia KCP Kudus. Sedangkan saving intention dapat memediasi pengaruh knowledge dan service quality terhadap saving decision di Bank Syariah Indonesia KCP Kudus.

\section{Ucapan Terimakasih}

Peneliti mengucapkan terimakasih kepada Fakultas Ekonomi dan Bisnis Islam Institut Agama Islam Negeri Salatiga, serta terimakasih kepada pihak Bank Syariah Indonesia KCP Kudus yang telah membantu dalam penelitian. 


\section{Referensi}

Ajzen, I. (1991). The Theory of Planned Behavior. OrganizationalBehavior and Human Decision Processes, 50, 179-211.

Ajzen, I., \& Fishbein, M. (1980). Understanding Attitudes and Knowledge Management. $9,59-74$.

Anburika, N. (2018). Pengaruh Minat Dan Preferensi Terhadap Keputusan Nasabah Memilih Produk-Produk Di Bank Syariah Mandiri Kantor Cabang Pembantu Tulungagung.

Antonio, M. S. (2001). Bank Syariah: Dari Teori ke Praktik. Jakarta: Gema Insani Press.

Engel, F. J., Blackwell, R., \& Miniard, P. (1995). Perilaku Konsumen. Jakarta: Binanupa Aksara.

Ferdinand, A. (2006). Metode penelitian manajemen. Semarang: Badan Penerbit Universitas Diponegoro.

Fitriya, E. (2017). Analisis Pengaruh Islamic Branding Terhadap Keputusan Konsumen Untuk Membeli Produk. JIAI (Jurnal IImiah Akuntansi Indonesia), 2, 31-41.

Hidayati, N. (2019). Analisis Pengaruh Lokasi, Promosi Dan Kualitas Pelayanan Terhadap Keputusan Nasabah Menggunakan Produk Bank Syariah MelaluiMinat Sebagai Variabel Intervening (Studi Kasus Pada Nasabah Bank BRI Syariah Kantor Cabang Pembantu Sragen). IAIN Salatiga.

Ibrahim, C., \& Rusdianto, H. (2016). Pengaruh Produk Bank Syariah Terhadap Minat Menabung dengan Persepsi Masyarakat Sebagai variabel Moderating di Pati. Jurnal Equilibrium, 4.

llamiyah, M. N. (2020). Pengaruh Islamic Branding, Service Quality, Dan Sales Promotion Terhadap Keputusan Memilih Bank Syariah Dengan Religiusitas Sebagai Variabel Moderating (Studi Kasus pada Nasabah PT. BPRS Sukowat Sragen Cabang Boyolali). IAIN Salatiga.

Kotler, P. (2000). Manajamen Pemasaran, Jilid 1\&2. Jakarta: PT Prenhallindo.

Kotler, P. (2002). Manajamen Pemasaran. Jakarta: PT Prenhallindo.

Laila, Z. N. (2018). Analisis Pengaruh Kualitas Pelayanan, Promosi Dan Pengetahuan Terhadap Keputusan Nasabah Menggunakan Produk Bank Syariah MelaluiMinat Sebagai Variabel Intervening (Studi Kasus Pada Nasabah Bank BRI Syariah Kantor Cabang MT. Haryono Semarang). IAIN Salatiga.

Lupiyoadi, R. (2009). Manajemen Pemasaran Jasa Edisi Ketiga. Jakarta: Salemba Empat.

Nafiah, Z. (2018). Pengaruh pengetahuan masyarakat tentang lembaga keuangan syariah dan tingkat religiusitas terhadap keputusan menjadi anggota BMT Yaummi Fatimah Pati Cabang Juwana. UIN Walisongo Semarang.

Nasrullah, M. (2015). Islamic Branding, Religiusitas Dan Keputusan Konsumen Terhadap Produk. Jurnal Hukum Islam (JHI), 13.

Nurlaeli, I. (2017). Pengaruh Faktor Budaya, Psikologi, Pelayanan, Promosi Dan Pengetahuan Tentang Produk Terhadap Keputusan Nasabah Memilih BPRS Di Banyumas. Islamadina Jurnal Pemikiran Islam, XVIII, 75-106. 
Nurlatifah, S. Z., \& Masykur, R. (2017). Pengaruh Strategi Pemasaran Word Of Mouth (WOM) Dan Produk Pembiayaan Syariah Terhadap Minat Dan Keputusan Menjadi Anggota (Nasabah) Pada Baitul Tamwil Muhammadiyah (BTM) Kota Bandar Lampung. Jurnal Manajemen Indonesia, 17, 163-170.

Polla, F. C., Mananeke, L., \& Taroreh, R. N. (2018). Analysis of the Influence of Price, Promotion, Location and Services Quality on Purchase Decisions in Pt. Indomaret Manado Unit Jalan Sea. Jurnal EMBA, 6(4), 3068-3077.

Prasetijo, R., \& Ihalauw, J. J. O. . (2005). Perilaku Konsumen. Yogyakarta: Andi.

Shobirin, Fathoni, A., \& Minarsih, M. (2016). Pengaruh Lokasi, Tingkat Suku Bunga Dan Kualitas Pelayanan Terhadap Keputusan Pengam bilan Kredit (Studi Em piris Pada BPR Arthanugraha Makmursejahtera). Journal OfManagement, 2.

Simamora, B. (2002). Panduan Riset Perilaku Konsumen. Jakarta: PT Gramedia Pustaka Utama.

Sukron, A. R. M. (2019). Pengaruh KemudahanPenggunaan, Islamic Branding dan EService Quality Terhadap Keputusan Pembelian di Tokopedia Dengan Minat Beli Sebagai Variabel Intervening. IAIN Salatiga.

Sunyoto, D. (2013). Perilaku Konsumen: Panduan Riset Sederhana untukMengenali Konsumen. Yogyakarta: CAPS.

Tjiptono, F. (2002). Manajemen Jasa Cetakan Kedua. Yogyakarta: Penerbit Andi.

Yunus, N. S. N. M., Rashid, W. E. W., Arifin, N. M., \& Rashid, N. M. (2014). Muslim's Purchase Intention towards Non-Muslim's: Halal Packaged Food Manufacturer. Procedia Social and Behavioral Sciences, 130, 145-154. 